\title{
PERMAINAN EDUKATIF UNTUK ANAK USIA DINI
}

\author{
Angga Saputra \\ Alumni Pascasarjana \\ Universitas Islam Sunan Kalijaga Yogyakarta \\ Email: pgraku@gmail.com
}

\begin{abstract}
Abstrack:
This article is entitled: Permanan Educative Early Childhood. With the aim is to know educational games for early childhood.

Educational games for early childhood, playing is one of the words that are quite familiar to our ears, especially if we become a teacher, especially for PAUD teachers. Game tools are all tools used by children to fulfill their instincts of play. The game tools in question are for example soccer balls from plastic cars, calluses, pistols, puppets, imitation of cooking tools and so on. So the educational game tool is all the game tools that children use to fulfill their instincts of play. So early childhood educational games are games that can meet the needs of children's play instincts.
\end{abstract}

Keywords: Educational Games, and Early Childhood.

\section{PENDAHULUAN}

Bermain merupakan salah satu kata yang cukup akrab di telinga kita, terutama kita menjadi seorang guru, bagi guru PAUD, bermain sering diintegrasikan dalam kegiatan belajar mengajar, karena dunia anak adalah dunia bermain. Meskipun demikian, tidak menutup kemungkinan guru, Sekolah Dasar (SD), guru Sekolah Menengah Pertama (SMP), dan Sekolah Menegah Atas (SMA) juga mengintegrasikan kegiatan bermain dalam dalam proses pembelajaran. Hal ini diyakini bisa meningkatkan minat dan aktivitas belajar siswa dalam mengikuti rangkaian kegiatan belajar-mengajar.

${ }^{1}$ Angga Saputra, M.Pd. Alumni Pasca Sarjana Universitas Islam Sunan Kalijaga Yogyakarta

Jurnal Pelangỉ Jurnal pemikiran dan penelitian pendidkan Islam anak Usia Dini 
Bermain merupakan salah satu kebutuhan, terutama bagi anak. Ada anggapan sebagian orang mengatakan bahwa bermain itu hanya buangbuang waktu, sebenarnya banyak keuntungan didapat seorang anak dengan bermain. Melalui bermain anak dapat melakukan kordinasi otot kasar, bermacam cara dan teknik dapat dipergunakan dalam kegiatan, seperti merayap, merangkak, berjalan, berlari, meloncat, melompat, menendang melipat, mengenggam, melempar dan lain sebagainya. ${ }^{2}$

Dengan bermain anak dapat berlatih menggunakan kemampuan kognitifnya, dapat mengembangkan kreatifitas, dapat melatih kemampuan bahasa, dapat meningkatkan kepekaan emosinya. Dengan bermain pula anak memperoleh kesempatan memilih kegiatan yang disukainya, bereksperimen dengan bermacam-macam bahan dan alat berimajinasi, memecahkan masalah dan bercakap-cakap secara bebas, berperan dalam kelompok, bekerja sama dalam kelompok, dan memperoleh pengalaman yang menyenangkan. ${ }^{3}$ Namun sebelum memilih jenis kegiatan bermain yang cocok dengan keadaan anak, guru harus mampu menentukan bentuk permainan yang di kategorikan edukatif maupun tidak yang mampu mencerdaskan anak.

Alat permainan edukatif dalam perkembangannya seringkali menggunakan istilah yang lain yaitu alat permainan edukatif yang disingkat APE. Misalnya seorang ahli bernama Sugiarto. T. Mengemukakan pendapatnya bahwa alat permaian eduatif (APE) adalah alat permainan yang sengaja dirancang secara khusus untuk kepentingan pendidikan. Pengertian alat permainan edukatif tersebut menunjukkan bahwa pada pengembangan dan pemanfaatannya tidak semua alat permainan yang digunakan anak usia dini dirancang secara khusus untuk mengembangkan aspek-aspek perkembangan anak. Sebagai contoh bola sepak yang dibuat dari plastik yang dibeli langsung dari toko mainan. Dalam hal ukurannya seringkali susah untuk dipegang dengan nyaman oleh anak, jika mau saling melempar dengan teman-temannya akan terasa sakit ditelapak tangan. Warnanya pun seringkali menggunakan satu warna saja sehingga tidak menarik bagi anak karena biasanya menyenangi bendabenda yang berwarna-warni.

Alat permainan akan membuka cakrawala berpikir, wawasan serta

\footnotetext{
${ }^{2}$ Mansur, Pendidikan Anak Usia Dini Dalam Islam, (Yogyakarta: Pustaka Pelajar, 2009), hlm, 149

${ }^{3}$ Moeslichatoen, Metode Pengajaran di Taman Kana-Kana, (Jakarta; Rineka Cipta, 2004), hlm, 33
} 
pengetahuan anak usia dini menjadi lebih luas, luwes dan kreatif tentang alat permainan edukatif sebagai salah satu sumber belajar yang mutlak dalam pendidikan anak Usia Dini. ${ }^{4}$

Alat permainan adalah semua alat yang digunakan anak untuk memenuhi kebutuhan naluri bermainnya. Alat permainan untuk anak dalam pengadaannya selain dapat dibeli di toko mainan juga dapat digali dan dikumpulkan dari sekeliling kita. Alat permainan yang dimaksud misalnya bola sepak dari plastik mobil-mobil, kapal-kapalan, pistolpistolan, boneka, tiruan alat-alat memasak dan lain sebagainya. ${ }^{5}$

Jadi alat permainan edukatif itu adalah semua alat permainan yang digunakan anak untuk memenuhi kebutuhan naluri bermain.

Anak usia dini adalah anak yang berada pada usia 0-8 tahun. Menurut Beichler dan Snowman dalam Dwi Yulianti, mengatakan bahwa anak usia dini adalah anak yang berusia antara 3-6 tahun. ${ }^{6}$ Sedangkan hakikat anak usia dini adalah individu yang unik dimana ia memiliki pola pertumbuhan dan perkembangan dalam aspek fisik, kognitif, sosioemosinal, kreativitas, bahasa dan komunikasi yang khusus yang sesuai dengan tahapan yang sedang dilalui oleh anak tersebut. ${ }^{7}$

Jadi anak usia dini adalah anak yang berusia antara 0 bulan hingga 8 tahun, lalu ada pula yang mengatakan bahwa anak usia dini adalah anak yang berusia antara 3 tahun hingga 6 tahun.

\section{A. Pengertian Permainan Edukatif}

Permainan edukatif adalah semua bentuk permainan yang dirancang untuk memberikan pengalaman pendidikan atau pengalaman belajar kepada para pemainnya, termasuk Permainan tradisional dan “modern" yang diberi muatan pendidikan dan pengajaran ${ }^{8}$ (Adams, 1975). Atas dasar pengertian itu, permainan yang dirancang untuk memberi

${ }^{4}$ Badru Zaman. Pengembangan Alat Permainan Edukatif di Lembaga Pendidikan Anak Usia Dini (PAUD), hal 2-3, yang diaksesdari: badruzaman.staf.upi.edu.files/2011/12 yang diakses tanggal 2019/02/20

${ }^{5}$ Ibid, hal. 3

${ }^{6}$ Skripsi. Pembelajaran melalui kegiatan bermain dengan benda-benda konkrit dapat mengembangkan kemampuan membilang kelompok A di Taman Kanak-Kanak Lembaga Tama III, Sutran Sabdodadi Bantul, Yogyakarta, hal 1, yang diakses dari: http: eprints.uny.ac.id/77778/3/bab2 yang diakses 2019/02/20, dikutip dari: Dwi Yulianti, 2010, 7)

${ }^{7}$ Ibid, hal. 1, Dikutip dari: Agusta, 2012

${ }^{8}$ Adams...

Jurnal Pelangi Jurnal pemikiran dan penelitian pendidkan Islam anak Usia Dini 
informasi atau menanamkan sikap tertentu, misalnya untuk memupuk semangat kebersamaan dan kegotong-royongan, termasuk dalam kategori permainan edukatif karena permainan itu memberikan pengalaman belajar kognitif dan afektif.

Dengan demikian, tidak menjadi persoalan apakah permainan itu merupakan permainan "asli" yang khusus dirancang (by design) untuk pendidikan ataukah permainan "lama" yang diberi nuansa atau dimanfaatkan (by utilization) untuk pendidikan. Permainan edukatif merupakan suatu kegiatan yang sangat menyenangkan dan dapat merupakan cara atau alat pendidikan yang bersifat mendidik dan bermanfaat untuk meningkatkan kemampuan berbahasa, berpikir serta bergaul dengan lingkungan atau untuk menguatkan dan menterampilkan anggota badan si anak, mengembangkan kepribadian, mendekatkan hubungan antara pendidik dengan peserta didik, kemudian menyalurkan kegiatan anak didik dan sebagainya.

Permainan edukatif juga dapat berarti sebuah bentuk kegiatan yang dilakukanuntuk memperoleh kesenangan dari cara atau media pendidikan yang digunakan dalam kegiatan bermain, yang disadari atau tidak, memiliki muatan pendidikan yang dapat bermanfaat dalam mengembangkan diri peserta didik.Artinya, permainan edukatif merupakan sebuah bentuk kegiatan mendidik yang dilakukan dengan menggunakan cara atau media permainan yang bersifat mendidik. Ringkasnya, permainan edukatif adalah permainan yang bersifat mendidik dan bisa mengembangkan daya kreativitas dan imajinasi anak.

Jadi permainan edukatif adalah permaian yang mendidik anak usia dini dilakukan dengan menggunakan cara-cara atau metode-metode atau media-media permainan yang sifatnya mendidik, sehingga mengembangkan daya kreativitas dan kognitif, afektif dan psikomotorik anak usia dini.

\section{B. Kategori Permainan Edukatif}

Sebagai seorang guru, mengaplikasikan berbagai permainan dalam kegiatan belajar-mengajar merupakan hal yang wajib dilakukan bagi anak usia dini. Suatu kegiatan belajar mengajar dapat berjalan efektif apa bila ada berbagai strategi yang berguna, baik berupa metode, model, pendekatan, maupun teknik. Salah satu yang dapat di terapkan pada anak 
usia dini adalah permainan yang bisa mencerdaskan.

Tidak semua permainan dapat dikategorikan sebagai permainan atau game/permainan edukatif. Nilai edukatif itu bisa didapatkan bila ada hal-hal yang bermanfaat bagi penggunanya, kemampuan problem solving (memecahkan masalah), meningkatkan kosentrasi, dan lain sebagainya. Berikut ialah beberapa hal yang dapat menjadi acuan permainan yang digunakan besifat edukatif atau tidak $:^{9}$

1. Sesuai dengan Sasaran

Bila sasaran dari permainan adalah untuk mengembangkan kognitif, efektif, bahasa, agama, sosial-emosi maupun psikomotorik Anak/siswa, maka permainan tersebut bisa dikategorikan sebagai permainan edukatif.

2. Multifungsi

Jika permainan itu tidak hanya mengembangkan kognitif, efektif, agama, bahasa, sosial-emosi, ataupun psikomotorik, melainkan penggabungan dari dua atau seluruh rana tersebut, maka permainan itu dikategorikan sebagai permainan edukatif.

3. Sesuai dengan tujuan

Apabila tujuan dari permainan tersebut jelas dan memiliki nilai edukatif. Misalnya, mengembangkan kemampuan problem solving, mengklarifikasi nilai, melatih kepemimpinan, ketangkasan, kemampuan berpikir cepat, mengasah berpikir kreatif, dan lain sebagainya.

4. Melatih konsep-konsep dasar

Banyak permainan edukatif yang merangsang konsep tentang operasi hitung (penjumlahan, pengurangan, pengenalan angka, pengenalan huruf, perkalian), memilih strategi, menghargai pendapat, serta konsep lainya. Bila permainan itu melatih konsep dasar, maka permainan itu dapat disebut permainan edukatif.

5. Merangsang Kreativitas

Permainan yang mampu mendorong anak berpikir kreatif, bisa dikatakan permainan edukatif.

Jadi kategori permainan edukatif pada anak usia dini adalah apabila didapatkan hal-hal yang bermanfaat bagi penggunanya, kemampuan

${ }^{9}$ Iva Rifa, Koleksi Game Edukatif Di Dalam Dan Luar Sekolah, (Jogjakarta: FlasBooks, 2012), hlm, 27

Jurnal Pelang̉i Jurnal pemikiran dan penelitian pendidkan Islam anak Usia Dini 
problem solving (memecahkan masalah), meningkatkan kosentrasi, dan lain sebagainya.

\section{Faktor-Faktor Yang Mempengaruhi Kegiatan Bermain}

Anak lebih menyukai berbagai kegiatan yang bersifat aktif, bukan yang pasif. Agar tujuan kegiatan bermain dapat tercapai dan jalanya permainan bisa berlangsung dengan baik, maka ada berbagai faktor yang mempengaruhi kegiatan bermain yang dilakukan oleh anak dan guru. Adapun beberapa faktor yang mempengaruhi tersebut adalah sebagai berikut : ${ }^{10}$

1. Kesehatan

Anak yang memiliki fisik sehat mengikuti kegiatan bermain dengan lebih aktif bila dibandingkan dengan anak yang tidak sehat. Energi yang dimiliki anak sangat banyak, sehingga perlu disalurkan dengan berbagai kegiatan permainan. Sehingga, mereka ingin menyalurkan energi tersebut melalui kegiatan permainan edukatif yang sesuai minat mereka.

2. Penerimaan sosial dari kelompok bermain

Jika anak diterima oleh kelompok bermainnya maka ia cenderung akan menyukai permainan ini. Sebaliknya, bila ia tidak merasa tidak diterima, diacukan, bahkan dibenci oleh kelompok bermainnya, maka ia cenderung tidak mau bermain dan terlibat aktif.

3. Tingkat kecerdasan

Kecerdasan setiap anak berbeda-beda, sehingga cenderung menikmati permainan yang sesuai dengan tingkat kecerdasannya. Tingkat kecerdasan itu juga bisa disesuaikan dengan tingkat perkembangan bahasa, moral, kognitif, maupun fisik. Biasanya, anak yang pandai cenderung lebih aktif dibandingkan dengan anak yang kurang pandai. Anak yang pandai juga lebih kreatif dan penuh rasa ingin tahu, sehingga kegiatan bermain secara aktif lebih banyak diminati oleh anak yang pandai.

4. Jenis kelamin

Dalam suasana dalam kelas, umumnya guru membuat permain-

${ }^{10}$ Ibid, hlm, 30 
an yang dapat dimainkan secara bersama-sama, yaitu anak laki-laki dan anak perempuan secara bersamaan. Namun, terkadang ada sekolah yang membatasi perbedaan gender tersebut, terutama di sekolah berbasis keagamaan. Maka, guru juga menyesuaikan hal itu dengan keadaan anak, asalkan masih berada dalam batas-batas yang sewajarnya.

Umumnya, anak laki-laki menyukai kegiatan yang sifatnya aktif dan membutuhkan gerak seluruh anggota tubuh, seperti berlari, memanjat, berkejaran dan lain sebagainya. Sementara itu anak perempuan cenderung menyukai kegiatan yang konstruktif dan yang lebih tenang. Meskipun demikian, tidak menutup kemungkinan anak laki-laki dan perempuan memiliki perbedaan kesukaan. Oleh karena itu, guru perlu menyeimbangkannya agar mereka memiliki porsi permainan yang sama dalam mengembangkan potensi-potensi yang dimiliki melalui kegiatan permainan edukatif.

5. Alat permainan

Tidak semua alat permainan bisa didapatkan dengan mudah dilingkungan sekolah. Ketersediaan alat permainan juga penting agar kegiatan bermain berjalan lancar dan tepat sasaran. Oleh karena itu guru dapat memilih permainan yang perlengkapannya mudah di peroleh di lingkungan sekolah ataupun rumah. Bila memungkinkan, guru juga meminta setiap siswa untuk membawa sendiri peralatan bermain sehingga tidak memberatkan guru. Selain itu guru harus kreatif membuat permainan dari barang-barang bekas, sehingga permainan berjalan dengan baik.

6. Lingkungan

Sesuaikan dengan lingkungan yang akan digunakan bermain dengan lingkungan yang tersedia. Jika memang tidak memungkinkan untuk dilakukan maupun di modifikasi, sebaiknya guru tidak menggunakan permainan tersebut. Lingkungan yang mendukung membuat kegiatan bermain lebih menyenangkan dan maksimal.

Jadi faktor-faktor yang mempengaruhi kegiatan bermain anak usia dini adalah Kesehatan, Penerimaan sosial dari kelompok bermain, Tingkat kecerdasan, Jenis kelamain, alat permainan, dan lingkungan. 


\section{Prinsip-Prinsip Dalam Permainan Edukatif (Mencerdaskan)}

Beberapa hal berikut ini perlu diperhatikan oleh guru dalam memilih permainan yang tepat, yaitu: ${ }^{11}$

1. Permainan harus menyenangkan

Usia anak pra-sekolah, terutama Taman Kanak-Kanak cepat mengalami kebosanan. Oleh karena itu, guru harus mengemas permainan yang efektif, terencara, dan tepat waktu, sehingga mereka tidak cepat bosan. Jangan menggunakan permainan yang sama berulang kali, agar tidak bosan. Sebaiknya, gantilah permainan atau buatlah permainan berselang-seling dari waktu ke waktu agar lebih menarik.

2. Tingkat kesulitan

Anak yang merasa permainan tersebut mudah, cenderung menyepelekannya atau tidak menarik. Jadi gurupun harus menyesuaikan dengan tingkat kesukaranya. Bila terlalu sulit atau terlalu mudah, siswa bisa cepat bosan dan tidak tertarik. Sebaiknya, permainan yang dilakukan sedang-sedang saja; tidak mudah dan juga tidak sulit.

3. Perkembangan

Perkembangan inteligensial antara anak usia dini dengan anak Sekolah Dasar (SD) dan Sekolah Menegah Pertama (SMP) berbeda. Oleh karena itu, setiap permainan di usahan melihat perkembangan anak itu sendiri artinya sesuai fase-fase perkembangannya. ${ }^{12}$

4. Keselamatan

Beberapa permainan ada yang cukup aman untuk diminati oleh anak Sekolah Dasar (SD) dan Sekolah Menegah Pertama (SMP), namun tidak aman untuk anak usia dini. Karena kita tahu anak usia dini adalah masa dimana belum tahu persis mana yang baik atau mana yang aman baginya dan ini juga di sebut dengan masa oral. Maka dari itu setiap bentuk permainan yang akan di mainkan oleh anak harus dari bahan-bahan yang aman dan tidak berbahaya.

Jadi prinsip-prinsip dalam permainan edukatif (mencerdaskan adalah) permainan harus menyenangkan, tingkat kesulitan, perkembangan dan keselamatan.

\footnotetext{
${ }^{11}$ Ibid, hlm, 36

${ }^{12}$ Ibid, hlm, 37
} 


\section{E. Macam-Macam Permainan Edukatif Yang Mencerdaskan}

\section{Permainan lego}

Permainan lego adalah suatu jenis permainan yang terdiri dari berbagai macam potongan aneka bentuk bangun ruang seperti balok, prisma ataupun tabung yang memiliki suatu sistem knock-down pada salah satu sisinya sehingga bisa dibongkar dan dipasangkan kembali. Permainan lego ini dapat disusun dan disatukan antara bagian agar terbentuk suatu bangun ruang yang variatif.

a Manfaat dari permainan lego

Berikut ini beberapa manfaat permainan lego bagi anak usia dini dan ini bisa dimainkan mulai anak usia 2-5 tahun, yaitu:

1) Kecerdasan Parsial

Kecerdasan persial atau kecerdasan ruang termaksut diantaranya kecerdasan dimensional balita dapat juga dilatih dan dikembangkan dalam menyusun potongan balok ataupun kubus ketika disusun secara vertikal ataupun horisontal. Konsep dasar bangun ruang bagi anak itu sendiri mengenai panjang, lebar, dan tinggi sebuah bangunan dapat dikenalkan sejak dini.

2) Kreatifitas dan imajinasi

Imajinasi dan kreatifitas anak dapat dilatih dan dikembangkan dalam permainan lego ini. Misalnya membuat rumah-rumahan atau robot-robotan yang memiliki keanekaragaman bentuk dan pola merupakan stimulasi dasar dalam mengembangkan daya kreatifitas dan imajinasi anak itu sendiri.

3) Analitis

Kemampuan analitis anak didasarkan pada pengamatan dan kesesuaian antara pilihan bentuk yang dibangun dengan model atau bentuk bangunan yang sesungguhnya. Misalnya bentuk atap rumah adalah segitiga sedangkan bentuk roda adalah bulat dan bentuk bola adalah bundar.

4) Keterampilan

Keterampilan dalam menyeimbangkan penyusunan balok atau potongan balok agar tidak mudah jatuh ataupun tetap kokoh dalam posisinya bisa dilatih juga.

5) Motorik halus 
Ketelitian dalam menyatukan atau memasangkan antara bentuk agar dapat menyatukan ini anak dapat melatih dan megembangkan kemampuan motorik halus. ${ }^{13}$

\section{Permainan Rubik}

Rubik adalah sebuah permainan yang mengasah kemampuan berimajinasi.terdapat enam warna (merah, orange, biru, hijau, kuning, dan putih) dan enam sisi. Permainan ini diciptakan oleh Erno Rubik. Erno Rubik (lahir di Budapest, Hongaria 13 Juli 1944, usia 67 tahun) adalah seorang penemu, pematung dan profesor arsitektur dari Hungaria.

a. Manfaatnya

Adapun manfaat dari rubik ini sendiri:

1) Melatih kecerdasan emosional anak, jadi jika sudah punya anak, kamu bisa memberikan permainan ini untuk dimainkan anak.

2) Melatih kesabaran anak

3) Melatih ketrampilan koordinasi, persepsi visual dari pemain

4) Melatih otak kanan dalam bermain rubik, karena akan menggunakan banyak imajinasi.

5) Melatih anak-anak untuk berhati-hati dalam mengambil tindakan atau keputusan. karena 1 gerakan yang salah, akan membuat permainan ini tidak selesai-selesai. ${ }^{14}$

\section{Permainan Puzzle}

Menurut Soemiarti Patmonodewo (1995: 83) kata puzzle dapat diartikan dengan bongkar pasang. Menurut Kamus Bahasa Inggris-Indonesia puzzle berarti teka-teki. Dina Indriana mengemukakan bahwa puzzle adalah sebuah permainan untuk menyatukan pecahan keping untuk membentuk sebuah gambar atau tulisan yang telah ditentukan. ${ }^{15}$ Sebagaimana dikemukakan oleh indriana. ${ }^{16}$ Puzzle memiliki keunggulan

\footnotetext{
${ }^{13}$ Angga Saputra. Permainan edukatif yang mencerdaskan. yang diakses di:

http://artikelkesehatananak.com/manfaat-mainan-lego-untuk-balita-2-5-tahun.html. di akses pada tanggal 4 Mei 2017.

${ }^{14}$ Angga Saputra. Permainan edukatif yang mencerdaskan. yang diakses di: http:// knowledgerizky.blogspot.co.id/2012/06/rubiks-cube.html. di akses pada tanggal 4 Mei 2017.

${ }^{15}$ Dina Indriana., Ragam Alat Bantu Media Pengajaran, (Yogyakarta: Diva Press Anggota IKAPI), 2011). hlm, 23.

${ }^{16} \mathrm{Ibid}, \mathrm{hlm}, 34$.
} 
yakni memiliki bermacam-macam warna sehingga menarik minat anak untuk belajar dan meningkatkan daya tahan anak dalam belajar Menurut AR. Suku Radja, puzzle dapat melatih sisi kreativitas dan pola berfikir siswa terhadap suatu tugas sederhana puzzle dapat melatih daya nalar serta kejelian siswa dalam menata ulang potongan pola. ${ }^{17}$ Dan masih banyak lagi permainan-permainan edukatif yang bisa dimainkan oleh anak untuk mengembangkan semua kecerdasan yang dimilikinya.

Jadi macam-macam permainan edukatif yang mencerdaskan adalah permainan lego, permainan rubik dan permainan puzzle.

\section{KESIMPULAN}

Berdasarkan hasil pembahasan diatas dapat disimpulkan sebagai berikut:

1. Permainan edukatif adalah semua bentuk permainan yang dirancang untuk memberikan pengalaman pendidikan atau pengalaman belajar kepada para pemainnya, termasuk Permainan tradisional dan "Moderen" yang diberi muatan pendidikan dan pengajaran.

2. Kategori permainan edukatif yaitu; (a) Sesuai dengan Sasaran (b) Multi fungsi (c) Sesuai dengan tujuan (d) Melatih konsep-konsep dasar (e) Merangsang Kreativitas.

3. Prinsip-Prinsip Dalam Permainan Edukatif (Mencerdaskan) yaitu; Permainan harus menyenangkan, tingkat kesulitan, Perkembangan dan Keselamatan.

4. Permainan-permainan yang mencerdaskan bagi anak misalnya, puzzle, lego, rubik dan lain-lainnya.

\section{REFERENSI}

AR Suku Radja, 2013, Kumpulan Judul Puzzle Kertas Paling Mendidik untuk anak, Yogyakarta: Laksana Kids,

Badru Zaman. Pengembangan Alat Permainan Edukatifdi Lembaga Pendidikan Anak Usia Dini (PAUD), yang diaksesdari: badruzaman.staf.upi.edu.

${ }^{17}$ AR Suku Radja, Kumpulan Judul Purzle Kertas Paling Mendidik untuk anak, (Yogyakarta: Laksana Kids, 2013), hlm. 56

Jurnal Pelang̉i Jurnal pemikiran dan penelitian pendidkan Islam anak Usia Dini 
files/2011/12 yang diakses tanggal 2019/02/20

Dina Indriana, 2011, Ragam Alat Bantu Media Pengajaran, Yogyakarta: Diva Press Anggota IKAPI.

Iva Rifa, 2012, Koleksi Game Edukatif Di Dalam Dan Luar Sekolah, Jogjakarta: FlasBooks.

Mansur, pendidikan Anak Usia Dini Dalam Islam, (Yogyakarta: Pustaka Pelajar, 2009

Moeslichatoen, Metode Pengajaran di Taman Kana-Kana, (Jakarta; Rineka Cipta, 2004),

Skripsi. Pembelajaran melalui kegiatan bermain dengan benda-benda konkrit dapat mengembangkan kemampuan membilang kelompok $A$ di Taman Kanak-Kanak Lembaga Tama III, Sutran Sabdodadi Bantul, Yogyakarta, hal 1, yang diakses dari: http: eprints.uny.ac.id/77778/3/bab2 yang diakses 2019/02/20, dikutip dari: Dwi Yulianti, 2010, 7) hal. 1, Dikutip dari: Agusta, 2012

Angga Saputra. Permainan edukatif yang mencerdaskan. yang diakses di: http://knowledgerizky.blogspot.co.id/2012/06/rubiks-cube.html. di akses pada tanggal 4 Mei 2017.

http:/ / knowledgerizky.blogspot.co.id/2012/06/rubiks-cube.html. di akses pada tanggal 4 Mei 2017.

http://artikelkesehatananak.com/manfaat-mainan-lego-untuk-balita2-5-tahun.html. di akses pada tanggal 4 Mei 2017 